\title{
Post-Transcriptional Control of Mating-Type Gene Expression during Gametogenesis in Saccharomyces cerevisiae
}

\author{
Randi Yeager ${ }^{1}$, G. Guy Bushkin ${ }^{2}$, Emily Singer ${ }^{1}$, Rui Fu ${ }^{3} \mathbb{D}$, Benjamin Cooperman ${ }^{1}$ and Michael McMurray ${ }^{1, *(\mathbb{D})}$ \\ 1 Department of Cell and Developmental Biology, University of Colorado Anschutz Medical Campus, \\ Aurora, CO 80045, USA; randi.yeager@cuanschutz.edu (R.Y.); esinger@skidmore.edu (E.S.); \\ benjamin.j.cooperman@cuanschutz.edu (B.C.) \\ 2 Whitehead Institute for Biomedical Research, Cambridge, MA 02142, USA; guybushkin@gmail.com \\ 3 RNA Biosciences Initiative, School of Medicine, University of Colorado, Aurora, CO 80045, USA; \\ rui.fu@cuanschutz.edu \\ * Correspondence: michael.mcmurray@cuanschutz.edu; Tel.: +1-303-724-6569
}

Citation: Yeager, R.; Bushkin, G.G.; Singer, E.; Fu, R.; Cooperman, B.; McMurray, M. Post-Transcriptional Control of Mating-Type Gene Expression during Gametogenesis in Saccharomyces cerevisiae. Biomolecules 2021, 11, 1223. https://doi.org/ 10.3390/biom 11081223

Academic Editors: James Konopka and Mark Rose

Received: 16 July 2021

Accepted: 14 August 2021

Published: 17 August 2021

Publisher's Note: MDPI stays neutral with regard to jurisdictional claims in published maps and institutional affiliations.

Copyright: (c) 2021 by the authors. Licensee MDPI, Basel, Switzerland. This article is an open access article distributed under the terms and conditions of the Creative Commons Attribution (CC BY) license (https:// creativecommons.org/licenses/by/ $4.0 /)$.

\begin{abstract}
Gametogenesis in diploid cells of the budding yeast Saccharomyces cerevisiae produces four haploid meiotic products called spores. Spores are dormant until nutrients trigger germination, when they bud asexually or mate to return to the diploid state. Each sporulating diploid produces a mix of spores of two haploid mating types, a and $\alpha$. In asexually dividing haploids, the mating types result from distinct, mutually exclusive gene expression programs responsible for production of mating pheromones and the receptors to sense them, all of which are silent in diploids. It was assumed that spores only transcribe haploid- and mating-type-specific genes upon germination. We find that dormant spores of each mating type harbor transcripts representing all these genes, with the exception of Mata1, which we found to be enriched in a spores. Mata1 transcripts, from a rare yeast gene with two introns, were mostly unspliced. If the retained introns reflect tethering to the $M A T$ a locus, this could provide a mechanism for biased inheritance. Translation of pheromones and receptors were repressed at least until germination. We find antisense transcripts to many mating genes that may be responsible. These findings add to the growing number of examples of post-transcriptional regulation of gene expression during gametogenesis.
\end{abstract}

Keywords: budding yeast; sporulation; gametogenesis; gene expression; splicing; antisense

\section{Introduction}

The establishment of mating type in the budding yeast Saccharomyces cerevisiae was one of the first genetic circuits controlling cell fate to be understood in mechanistic detail. The circuitry and signal transduction pathways by which mating types manifest have been reviewed extensively [1-4] (Figure 1a). Two mating types, a and $\alpha$, differ genetically by only a few thousand basepairs of DNA at a single locus $(M A T)$, representing two alternative alleles that encode either the Mata1 and Mata2 or the Mat $\alpha 1$ and Mat $\alpha 2$ proteins. Mata2 has no known function. Mata1 and Mat $\alpha 2$ are homeodomain proteins that together form a heterodimeric transcriptional repressor of a small number of genes ( 20) important for mating by haploid cells of both mating types [5], including MAT $\alpha 1$. Mata1-Mat $\alpha 2$ also represses $R M E 1$, which inhibits meiosis and sporulation, the partially coupled processes by which diploid cells produce (usually) four haploid spores, two a and two $\alpha$. Mat $\alpha 2$ binds to the constitutively expressed protein $\mathrm{Mcm} 1$ to form a heterotetramer that represses a smaller number of genes (seven) mostly important for mating by a cells [5]. Finally, Mat $\alpha 1$ and Mcm1 form a complex that activates five genes mostly important for mating by $\alpha$ cells [5]. a cells produce and secrete a pheromone (a-factor) that is detected by a G-protein-coupled receptor expressed only in $\alpha$ cells, and $\alpha$ cells produce and secrete a pheromone ( $\alpha$-factor) that is detected by a G-protein-coupled receptor expressed only in a cells. Thus the few gene expression differences arising from the identity of the allele at MAT are sufficient 
to confer three distinct cell fates: mating as a, mating as $\alpha$, or non-mating but capable of meiosis/sporulation $(\mathbf{a} / \alpha)$.

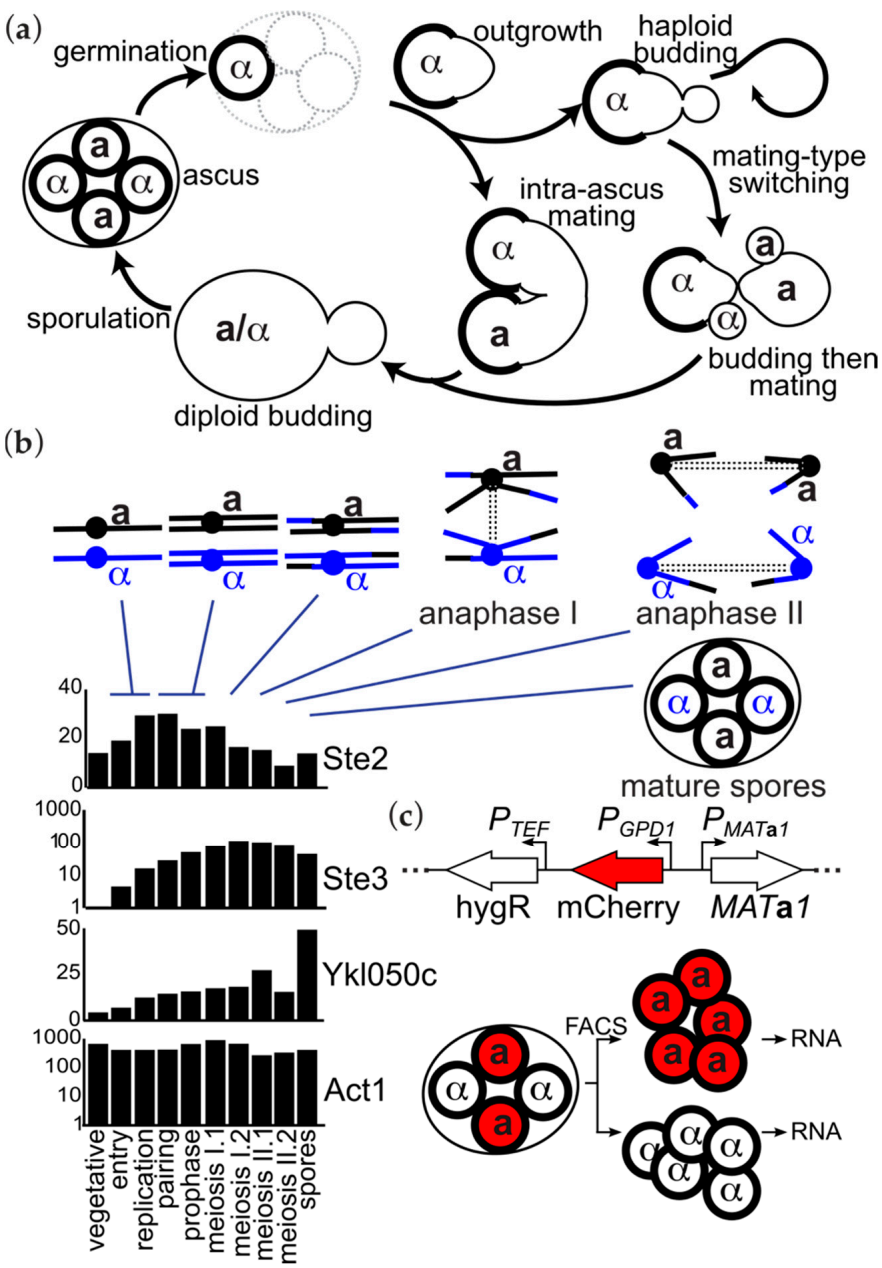

Figure 1. Early accumulation of mating-type-specific transcripts during S. cerevisiae and an approach to determine their inheritance in spores separated by mating type. (a) A simplified illustration of the life cycle of $S$. cerevisiae. Diploid cells undergo meiosis and sporulation, typically producing four haploid spores within each sporulating cell. Each spore is encased in a specialized wall (thicker lines) that confers resistance to a variety of environmental stressors. The two mating types, a and $\alpha$, reflect alternative alleles at a single locus. Meiosis usually produces two pairs of spores of opposite mating types, which remain largely dormant until they germinate. After germination, spores can either bud or mate, often with another spore from the same ascus. Haploid budding can proceed indefinitely, or mating can occur at any point, given an appropriate partner. A haploid spore from most natural isolates is able to switch mating types and, via subsequent mating with one of its offspring, return to the diploid state. (b) Bar graphs show published data [6] with levels of the indicated transcripts as assessed by RNA-seq from cells taken at various time-points from synchronously-sporulating cultures. Major cellular events at each time-point are listed below and illustrated above, for a single representative chromosome (Chr. III) that also harbors the mating-type locus near its centromere. Data represent composite values from two methods of synchronized sporulation. Note that some $y$ axes are in $\log$ scale. The spore-autonomous gene YKLO50C is shown as an example of the expression pattern expected for transcripts inherited only by the spores that inherit the encoding allele. (c) Illustration of the FASTER-MT method [7] for isolating a and $\alpha$ spores via fluorescenceactivated cell sorting (FACS). The spore-autonomous GPD1 promoter drives expression of mCherry and is inserted at the mating-type locus with the a allele, encoding Mata1. "hygR", the hygromycin-resistance gene $h$ ph under control of the heterologous TEF promoter. Illustration is not to scale. 
The genetic circuitry that controls these cell fates is also nimble. Haploid cells of most natural isolates of $S$. cerevisiae are able to switch mating types. Mating-type switching is thought to have evolved to allow isolated haploid spores a relatively rapid pathway to diploidy [8]. Switching occurs by a gene conversion event following a double-strand DNA break at $M A T$, swapping with the silent mating type loci cassettes harboring the $M A T \mathbf{a} 1$ and $M A T \mathbf{a} 2$ or the MAT $\alpha 1$ and $M A T \alpha 2$ protein-coding genes [4]. The phenotypic switch is completed within a cell cycle after the genetic switch [9], indicating that all proteins dictating sexual identity, including the mating pheromone secreted and the receptor that senses the other pheromone (Ste3 or Ste2), are rapidly turned over and replaced by their mating-type-appropriate counterparts. Failure to turn over key proteins such as Ste 2 or MAT $\alpha 2$ upon mating-type switching leads to defects in the manifestation of the new sexual identity [10]. Mating itself represents another transition in cell type-from mating-competent to non-mating - that must be accomplished efficiently: after haploid cells fuse, the expression and/or activity of pheromones and their receptors must be quickly extinguished to prevent autocrine signaling leading to cell cycle arrest [11].

Sporulation is the other step in yeast life cycle that requires a transition between sexual identities, from non-mating $(\mathbf{a} / \alpha)$ to mating-competent (a and $\alpha)$. Considering the importance in other transitions of preventing inappropriate expression of mating-typedetermination genes, we were surprised to notice, in the data from a transcriptome-wide study of gene expression during sporulation [6], that haploid- and mating-type specific transcripts began to appear long before individual spores become isolated from each other by the de novo formation of cell membranes and walls (Figure 1b). Indeed, many such transcripts, including Ste2 and Ste3, appear even prior to meiotic recombination (Figure 1b) [6]. If these transcripts are inherited by every spore regardless of which allele at MAT it inherits, then an a spore would inherit transcripts normally appropriate for expression in an $\alpha$ spore, and vice versa. Here, we investigate this phenomenon by sorting spores according to their MAT allele and profiling their transcriptomes. We find evidence of multiple mechanisms that control sexual expression in spores.

\section{Materials and Methods}

Diploid strain FW2444 (SK1 background $P_{C U P 1}$-IME1::kanMX/PCUP1-IME1::kanMX) [12] was transformed using the Zymo Research Frozen-EZ Yeast transformation II Kit (\#T2001) with StuI-cut pBC58 [7] to integrate the $P_{G P D 1}-m$ Cherry cassette at MATa. The diploid strain

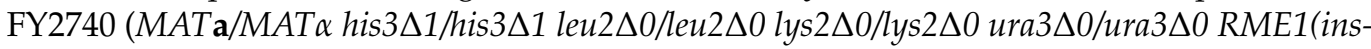
308A)/RME1(ins-308A) TAO3(E1493Q)/TAO3(E1493Q) MKT1(D30G)/MKT1(D30G) [13] was similarly transformed with uncut pNeo-MagicFluor [14], which was a gift from Leonid Kruglyak (Addgene plasmid \#58564; http:/ /n2t.net/addgene:58564, accessed on 16 August 2020; RRID:Addgene_58564). G-418 selection for this plasmid was maintained in the rich medium growth prior to transfer to sporulation medium. GBy6 is in the same background as FY2740 but homozygous for mutations in the IME4 catalytic

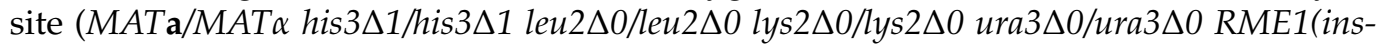
308A)/RME1(ins-308A) TAO3(E1493Q)/TAO3(E1493Q) MKT1(D30G)/MKT1(D30G) ime4-

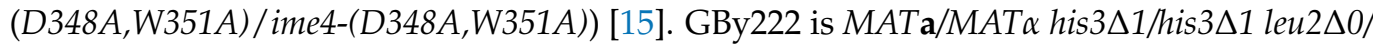
leu $2 \Delta 0$ lys2 $\Delta 0 /$ lys $2 \Delta 0$ ura3 $\Delta 0 /$ ura3 $\Delta 0$ TAO3(E1493Q)/TAO3(E1493Q) MKT1(D30G)/MKT1 (D30G) [15]. GBy225 is MATa/MAT $\alpha$ his $3 \Delta 1 /$ his $3 \Delta 1$ leu $2 \Delta 0 /$ leu $2 \Delta 0$ lys $2 \Delta 0 /$ lys $2 \Delta 0$ ura $3 \Delta 0 /$ ura3 $\triangle 0$, with the S288C alleles at RME1, TAO3, and MKT1 [15].

To prepare cells for RT-PCR, cells were grown in YPD supplemented with $4 \%$ glucose for $25 \mathrm{~h}$ at $30{ }^{\circ} \mathrm{C}$ with shaking and diluted to an $\mathrm{OD}_{600}$ of $0.2 \mathrm{in} \mathrm{BYTA}$ medium (1\% yeast extract, $2 \%$ tryptone, $1 \%$ potassium acetate, $50 \mathrm{mM}$ potassium phthalate). BYTA cultures were grown for an additional $16.5 \mathrm{~h}$ at $30{ }^{\circ} \mathrm{C}$ with shaking. Cells were washed once with water, re-suspended in $0.3 \%$ potassium acetate to $\mathrm{OD}_{600}$ of 2 , and incubated at $30{ }^{\circ} \mathrm{C}$ with shaking.

To prepare spores for sorting by mating type, 25-mL cultures of FW2444 cells with integrated $\mathrm{pBC} 58$ were grown in liquid YPD ( $2 \%$ peptone, $2 \%$ glucose, $1 \%$ yeast extract) 
medium supplemented with (per L) $0.096 \mathrm{~g}$ L-tryptophan, $0.024 \mathrm{~g}$ uracil, and $0.012 \mathrm{~g}$ adenine at $30{ }^{\circ} \mathrm{C}$ in $250-\mathrm{mL}$ flasks with shaking to exponential phase. Cells from these cultures were used to inoculate new 25-mL cultures of reduced-glucose YPD (1\% glucose) supplemented with (per L) $0.024 \mathrm{~g}$ uracil and $0.012 \mathrm{~g}$ adenine to an $\mathrm{OD}_{600}$ of 0.05 . These cultures were grown at $30^{\circ} \mathrm{C}$ with shaking to $\mathrm{OD}_{600}$ of $\sim 12$, then pelleted and washed with sterile water twice, and suspended in copper-containing sporulation medium (1\% potassium acetate, pH 7.0, $0.04 \mathrm{~g} / \mathrm{L}$ adenine, $0.04 \mathrm{~g} / \mathrm{L}$ uracil, $0.02 \mathrm{~g} / \mathrm{L}$ histidine, $0.02 \mathrm{~g} / \mathrm{L}$ leucine, $0.02 \mathrm{~g} / \mathrm{L}$ tryptophan, and $0.02 \%$ raffinose, $50 \mu \mathrm{M}$ copper (II) sulfate) to an $\mathrm{OD}_{600}$ of 2.5 . Cells were incubated with shaking at $30^{\circ} \mathrm{C}$ and harvested for sorting seven days after copper induction of sporulation.

For fluorescence-activated cell sorting (FACS), asci were digested enzymatically to remove the ascus wall and sorted essentially as described previously [7] using a BD FACSAria (BD Biosciences) in the Allergy and Clinical Immunology/Infectious Disease (ACI/ID) Flow Core of the University of Colorado Anschutz Medical Campus. Between 8 and 30 million cells of each color were used for RNA extraction.

\subsection{RNA Sequencing and Data Analysis}

Sorted spores were harvested by centrifugation and frozen in liquid nitrogen. Total RNA was isolated by hot acid phenol extraction, as follows. Thawed cells were resuspended in $400 \mu \mathrm{L}$ cold TES (10 mM Tris-HCl, pH 7.5, 1 mM EDTA, 0.5\% SDS). Then, $400 \mu \mathrm{L}$ acid phenol:chloroform was added and the mixture was vortexed for $15 \mathrm{~s}$ in tubes pre-filled with garnet and zirconium satellites (\#PFMM 500-100-25, OPS Diagnostics). The 15-s intervals of vortexing continued over the course of $30 \mathrm{~min}$ with 5 -min intervals of incubation at $65{ }^{\circ} \mathrm{C}$ in between. After incubation on ice for $5 \mathrm{~min}$, the tubes were centrifuged at 14,000 rpm for $10 \mathrm{~min}$ at $4{ }^{\circ} \mathrm{C}$. The aqueous layer was transferred to a new tube and the RNA was precipitated with sodium acetate and ethanol. Then, $100 \mathrm{ng}$ total RNA was used as input for library preparation with a Tecan Universal Plus mRNA-seq Library Preparation Kit with NuQuant (Cat \# 0520). Sequencing was completed using an Illumina NovaSEQ 6000 Instrument using v1.5 Chemistry with S4 Flow Cell at the Genomics Core of the University of Colorado Anschutz Medical Campus. Reads were aligned by STAR v2.7.3a to a modified version of the S288c reference genome (R64-1-1) containing sequences of the mCherry and hygromycin resistance gene, and then quantified by FeatureCounts from Subread using paired setting. Downstream analysis was performed in R using edgeR [16] to normalize data to counts per million for quantification of differentially expressed genes between mating types with a generalized linear model accounting for batch effect. To prepare images of read coverage, images were exported either from a custom track on the genome browser of the University of California Santa Cruz Genomics Institute [17] or using IGV (Integrative Genomics Viewer) version 2.4.19 [18].

\subsection{Quantitative Reverse Transcription PCR}

RNA was extracted from frozen cells (equivalent to $24 \mathrm{~mL}$ of culture at $\mathrm{OD}_{600}=1$ ) by first vortexing in $600 \mu \mathrm{L} \mathrm{AE} \mathrm{buffer} \mathrm{(50} \mathrm{mM} \mathrm{sodium} \mathrm{acetate,} 10 \mathrm{mM}$ EDTA, 1\% SDS) and $600 \mu \mathrm{L}$ acid phenol in the presence of $\sim 100 \mu \mathrm{L}$ acid-washed glass beads at $4{ }^{\circ} \mathrm{C}$ for $5 \mathrm{~min}$. The mixture was incubated at $65^{\circ} \mathrm{C}$ for $10 \mathrm{~min}$. Next, cells were vortexed again, incubated at $65^{\circ} \mathrm{C}$ for $10 \mathrm{~min}$ again, vortexed, and pelleted at $18,400 \times \mathrm{g}$ for $10 \mathrm{~min}$ at $4{ }^{\circ} \mathrm{C}$. The aqueous top phase was transferred to a new tube and extracted again in phenol. After another centrifugation and transfer to a new tube, RNA was extracted in $400 \mu \mathrm{L}$ chloroform followed by ethanol precipitation. cDNA was generated with SuperScript III (Life Technologies, Carlsbad, CA, USA) using random hexamers or gene-specific primers from $1 \mu \mathrm{g}$ of total RNA. RT-qPCR was performed using SYBR green PCR master mix (Life Technologies, Carlsbad, CA, USA) with primers TTCCATCCAAGCCGTTTTGT and CAGCGTAAATTGGAACGACGT for ACT1 and ATGGATGATATTTGTAGTATGGCG and TTATTTAGATCTCATACGTTTATTTATGA for all forms of unspliced and spliced Mata1, or GAAATCAATCT- 
CAATACTAATAATCTTT and ACGTTTATTTATGAATCTTACTTGAAGTG for MATa1 on Applied Biosystem 7500 or QuantStudio 5 instruments.

\subsection{Microscopy}

Cells were grown to saturated in liquid YPD ( $2 \%$ glucose) medium overnight at $30{ }^{\circ} \mathrm{C}$, from which $200 \mu \mathrm{L}$ was added to $5 \mathrm{~mL}$ of sterile water and pelleted. The cells were resuspended in $2.5 \mathrm{~mL} 1 \%$ potassium acetate and cultured at $30{ }^{\circ} \mathrm{C}$, rotating in glass culture tubes for 4 days. To induce germination, aliquots of the sporulation culture were pelleted and resuspended in YPD ( $2 \%$ glucose) for 2 or $5 \mathrm{~h}$, at which point they were pelleted again and resuspended in water before spotting a 3- $\mu \mathrm{L}$ aliquot on a $1 \%$ agarose pad on a microscope slide. After the liquid was absorbed by the pad, the cells were covered with a coverslip. Imaging was performed on an EVOSfl all-in-one microscope (Thermo-Fisher, Waltham, MA, USA) with a $60 \times$ oil objective and transmitted light, GFP, or Texas Red LED cubes. Images were processed with FIJI [19].

\section{Results}

\subsection{Only One Transcript Distinguishes the Transcriptomes of Spores of Distinct Mating Types}

Several "spore-autonomous" genes, including GPD1 and $Y K L 050 C$, have been previously exploited to create fluorescent markers that allow fluorescence-activated cell sorting (FACS) of spores carrying a specific allele at a given locus [20,21]. To separate $\mathbf{a}$ and $\alpha$ spores we used the FASTER-MT system, which relies on a cassette integrated into the MATa2 gene in which the GPD1 promoter drives spore-autonomous expression of mCherry [7] (Figure 1c). We then isolated total RNA from the spore populations and sequenced mRNA using paired-end Illumina sequencing. We repeated the sporulation and sorting steps to generate two independent biological replicates. Spores exhibit little ongoing transcription $[22,23]$. Hence, we interpreted the presence of transcripts in spores as those produced and stably inherited during sporulation.

The abundance of only four transcripts was different between the two mating types, according to a false-discovery statistic of $5 \%$ (Figure 2a). Though the presence of mCherry protein was no guarantee of mRNA persistence, we found mCherry transcripts only in a spores, providing a positive control. We also found spore-autonomous inheritance of the transcript encoding the hygromycin resistance protein (hygromycin B phosphotransferase, or hph) that was used to select for integration of the $P_{G P D 1}-m$ Cherry cassette (Figure 2a,b). The heterologous promoter controlling expression of this gene, TEF, from the Ashbya gossypii gene encoding EF- $1 \alpha$, is expected to be constitutive during vegetative proliferation [24] but its activity during sporulation is unknown. If, like $Y K L 050 C$, it is mainly active late in sporulation, after spore membranes close (Figure 1b), and if transcripts made earlier in sporulation are turned over quickly, this could explain the observed spore-autonomous inheritance. RNA isolation took place more than a week after sporulation was induced (see Section 2). Robust detection of mCherry and hph thus suggests that in mature spores these transcripts are extremely stable.

Our unbiased quantitative comparisons indicated that RNA-seq reads mapping to YAR064W, a fragment of a pseudogene located in a largely silent subtelomeric region, were also enriched in a spores (Figure 2a). However, closer inspection revealed that most reads mapped to the periphery of the $Y A R 064 \mathrm{~W}$ coding region and likely represented the ends of transcripts from adjacent, unannotated regions that themselves were not differentially represented (Figure $2 b$ ). Thus, we think there are no actual differences in expression or inheritance of YAR064W.

The final gene that was found in unequal abundance in spores of different mating types was Mata1, which was enriched in a spores compared to $\alpha$ spores (Figure 2). Because the $P_{G P D 1}-m$ Cherry cassette is integrated nearby MATa1 (Figure 1c), we cannot exclude the possibility that whatever property of the GPD1 promoter makes it spore-autonomous is conferred onto MATa1. However, we find this explanation unlikely for two reasons. First, since the cassette is inserted between the first and second codons of Mata2, the bidirectional 
MATa1/a2 promoter remains intact, and 296 basepairs separate the $P_{G P D 1}-m C h e r r y$ cassette from the MATa1 coding sequence. Second, the GPD1 promoter only drives transcription of heterologous genes in one direction [25].

(a)

spore-autonomous
\begin{tabular}{|l|c|c|c|}
\hline Gene & $\begin{array}{c}\text { Log fold } \\
\text { change }\end{array}$ & P value & $\begin{array}{c}\text { False } \\
\text { discovery }\end{array}$ \\
\hline hph & 5.2 & $1.5 \times 10^{-29}$ & $8.5 \times 10^{-26}$ \\
\hline YAR064W & 9.1 & $2.7 \times 10^{-5}$ & 0.04 \\
\hline mCherry & 8.6 & $2.9 \times 10^{-5}$ & 0.04 \\
\hline MATa1 & 6.5 & $3.8 \times 10^{-5}$ & 0.04 \\
\hline
\end{tabular}

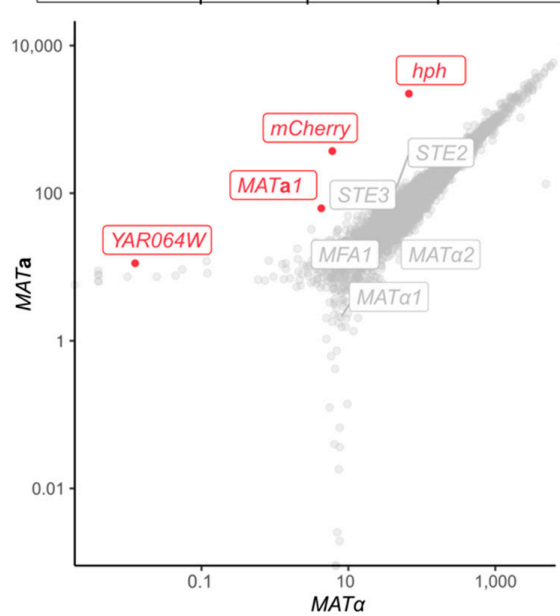

(b)

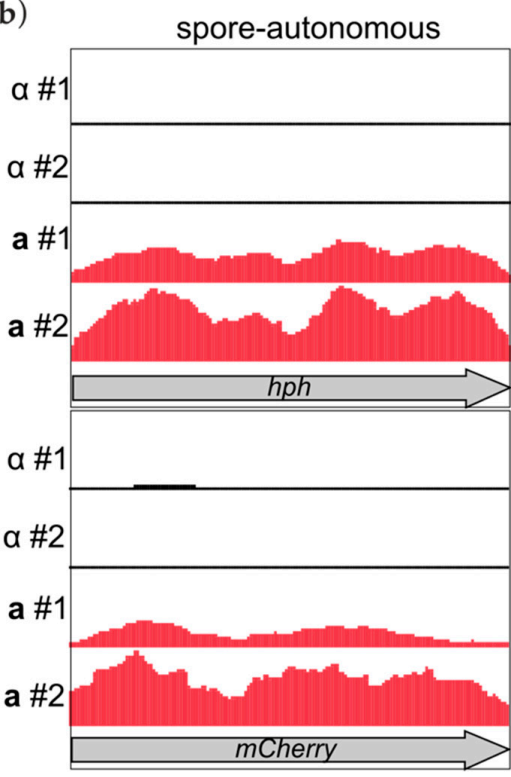

shared

\begin{tabular}{|l|c|c|c|}
\hline Gene & $\begin{array}{c}\text { Log fold } \\
\text { change }\end{array}$ & P value & $\begin{array}{c}\text { False } \\
\text { discovery }\end{array}$ \\
\hline MATa1 & -1.9 & 0.19 & 1.0 \\
\hline MATa2 & -0.60 & 0.34 & 1.0 \\
\hline STE2 & 0.56 & 0.33 & 1.0 \\
\hline STE3 & 0.41 & 0.58 & 1.0 \\
\hline MFa1 & 0.78 & 0.26 & 1.0 \\
\hline MFA1 & 0.87 & 0.27 & 1.0 \\
\hline ASG7 & 0.95 & 0.30 & 1.0 \\
\hline
\end{tabular}

spore-autonomous

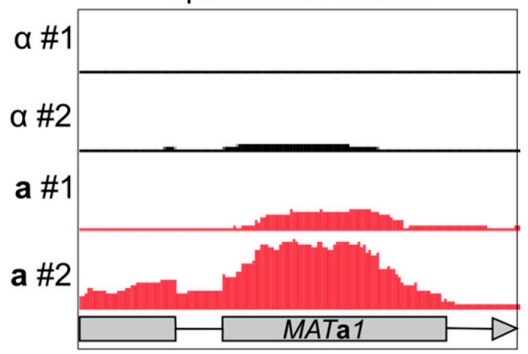

false positive

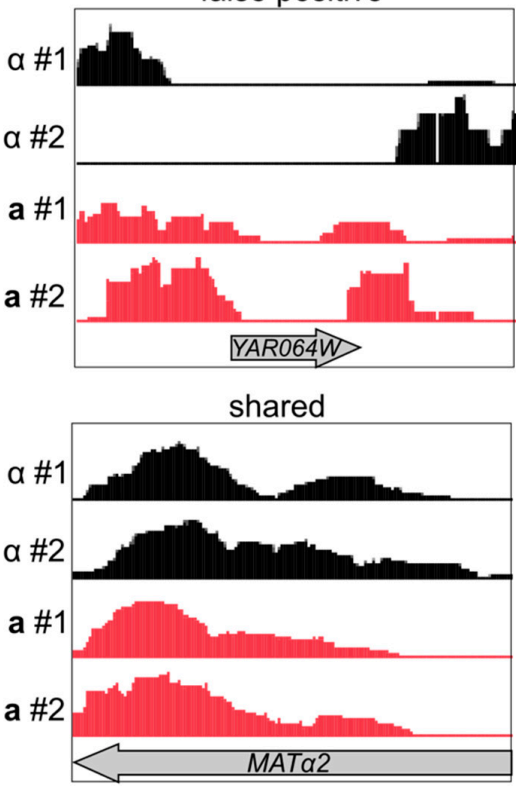

Figure 2. Inheritance of most "mating-type-specific" transcripts is independent of spore mating type. (a) RNA-seq data were analyzed by edgeR to identify transcripts for which abundance differed significantly between spores of each mating type. Values for ten transcripts of interest are shown in the tables. All but the four in the "spore-autonomous" table were shared approximately equally, according to a false-discovery statistic of $<0.05$. The correlation plot below highlights those four in red. (b) RNA-seq reads mapped onto the genome for the two biological replicates of the red ("a") and not red (" $\alpha$ ") sorted spores. Shown are the four transcripts considered "spore-autonomous" in (a) and Mat $\alpha 2$ as an example of a "shared" transcript. Gene structures are illustrated below. For each transcript, the scale of the $y$ axis is the same between all four samples. 


\subsection{Accumulation of Unspliced Mata1 Transcripts in MATa Spores}

Mata1 harbors two small introns [26]. We noticed that the Mata1 transcripts in a spores were incompletely spliced (Figure $2 b$ ). To independently confirm intron retention in Mata1 transcripts, we harvested RNA at specific time-points from synchronously sporulating diploid cells and performed RT-PCR with Mata1-specific primers, or primers targeting a control transcript, Act1, which encodes yeast actin. These data also showed intron retention in Mata1 transcripts, particularly at later stages of sporulation (Figure 3a), consistent with published microarray-based studies [27] (Figure 3b). The appearance of "new", unspliced transcripts during sporulation demonstrates that MATa1 transcription is ongoing, as opposed to a burst of early transcription in sporulating cells that produces extremely stable transcripts. Late in sporulation, the induction of ribosomal protein genes, 100 of which contain introns, overwhelms the splicing machinery, leading to a widespread defect in splicing efficiency [27]. We chose 90 intron-containing genes somewhat arbitrarily (86 that were examined in a previous study [28] plus four randomly-selected ribosomal protein genes) and looked for evidence of intron retention in our spore RNA-seq data. Notably, 49 of the 90 genes (54\%) had apparent intron retention, 23 were efficiently spliced and 18 were ambiguous (Table 1; see examples in Figure 3c). It has been proposed that the very short sizes of the Mata1 introns (52 and 54 nucleotides) leads to inefficient splicing even in wild-type vegetative cells [29], but there was no clear bias toward short introns among those with retained introns: the minimum intron length was 56 or 58 nucleotides in the genes with or without intron retention, and the median and mean intron lengths were greater in the genes with retained introns than in those without (99 vs. 96 and 184.8 vs. 173.1, respectively). These findings suggest that introns are retained in many transcripts produced during sporulation. For Mata1, the incomplete splicing was also associated with mating-type-specific RNA inheritance. Since we sorted spores solely on the basis of genotype at MAT, and our strain was homozygous at all other loci, our experiments do not address whether for other genes intron retention might correlate with biased segregation/inheritance during sporulation.

Table 1. Intron retention in spore transcripts. RNA-seq reads from sorted spores were analyzed for 90 intron-containing genes to classify them as to the efficiency of their splicing in spores. The number of genes in each splicing efficiency category is given in parenthesis.

\begin{tabular}{|c|c|c|}
\hline Genes with Retained Introns (49) & $\begin{array}{c}\text { Genes with No Obvious Intron } \\
\text { Retention }{ }^{1}(23)\end{array}$ & Ambiguous Genes (18) \\
\hline $\begin{array}{c}\text { AMA1, APE2, ARP2, COF1, COX5B, DBP2, } \\
\text { DCN1, DYN2, ECM33, ERV1, GCR1, GPI15, } \\
\text { HNT1, HNT2, HOP2, LSM2, MCM21, } \\
\text { MND1, MOB1, MRK1, MRPL44, MUD1, } \\
\text { NSP1, PCH2, PFY1, PMI40, POP8, QCR10, } \\
\text { QCR9, REC107, RPL17A, RPL22B, RPS17A, } \\
\text { RPS18B, RUB1, SCS22, SMD2, STO1, TAD3, } \\
\text { UBC13, UBC5, UBC9, VMA10,VMA9, } \\
\text { YML6, YOP1, YRA1, YSC84, YSF3 }\end{array}$ & $\begin{array}{c}\text { ACT1, BIG1, BUD25, COX4 }{ }^{2} \text { DMC1, } \\
\text { GIM5, GLC7, LSB3, LSM7, MMS2, } \\
\text { MOB2, MPT5, PHO85, PRE3, RAD14, } \\
\text { RFA2, RIM1, SAE3, SRC1, TAN1, TUB1, } \\
\text { UBC4, UBC8 }{ }^{1}\end{array}$ & $\begin{array}{c}\text { ARP9, CIN2, CPT1, EPT1, HFM1, IMD4, } \\
\text { MEI4, MTR2 2, NMD2, REC102, REC114, } \\
\text { SPO1, SPO22, SPT14, TUB3, UBC12, } \\
\text { VPS75, YBR220C }\end{array}$ \\
\hline
\end{tabular}

\subsection{Antisense Transcripts Corresponding to "Mating-Type-Specific" Genes Are Pervasive in Spores}

Our results demonstrate that the vast majority of genes present in a mating-typespecific manner in vegetative haploid cells are not mating-type-specific in spores, consistent with their accumulation early in sporulation before the cytoplasm is partitioned into the individual spores, and slow or no turnover thereafter. The same study reporting transcript levels during a time-course of sporulation also analyzed translation via ribosome profiling/Ribo-seq [6]. The numbers of ribosome-protected reads relative to the number of total reads were used to estimate translational efficiency. Ste3 had the 18th-lowest translational efficiency in unsorted spores [6]. Antisense transcripts corresponding to genes 
under mating-type control are known to affect both the ability to enter sporulation [30] and its progression [31]. We thus wondered whether antisense transcripts capable of regulating the translation of Ste3 might be made during sporulation. A large region of STE3 overlaps with YKL177W, a dubious ORF with no known function transcribed in the opposite direction (Figure 4a). We noticed from published microarray studies that in vegetative cells differing only by mating type Ykl177w transcript levels correlate inversely with Ste3 levels (Figure 4b) [32]. By contrast, in spores of each mating type we found reads representing both Ykl177w and Ste3 transcripts (Figure 4a). We did not detect the putative antisense transcript MUT940 [31], which is complementary to the STE3 3'UTR (Figure 4a).

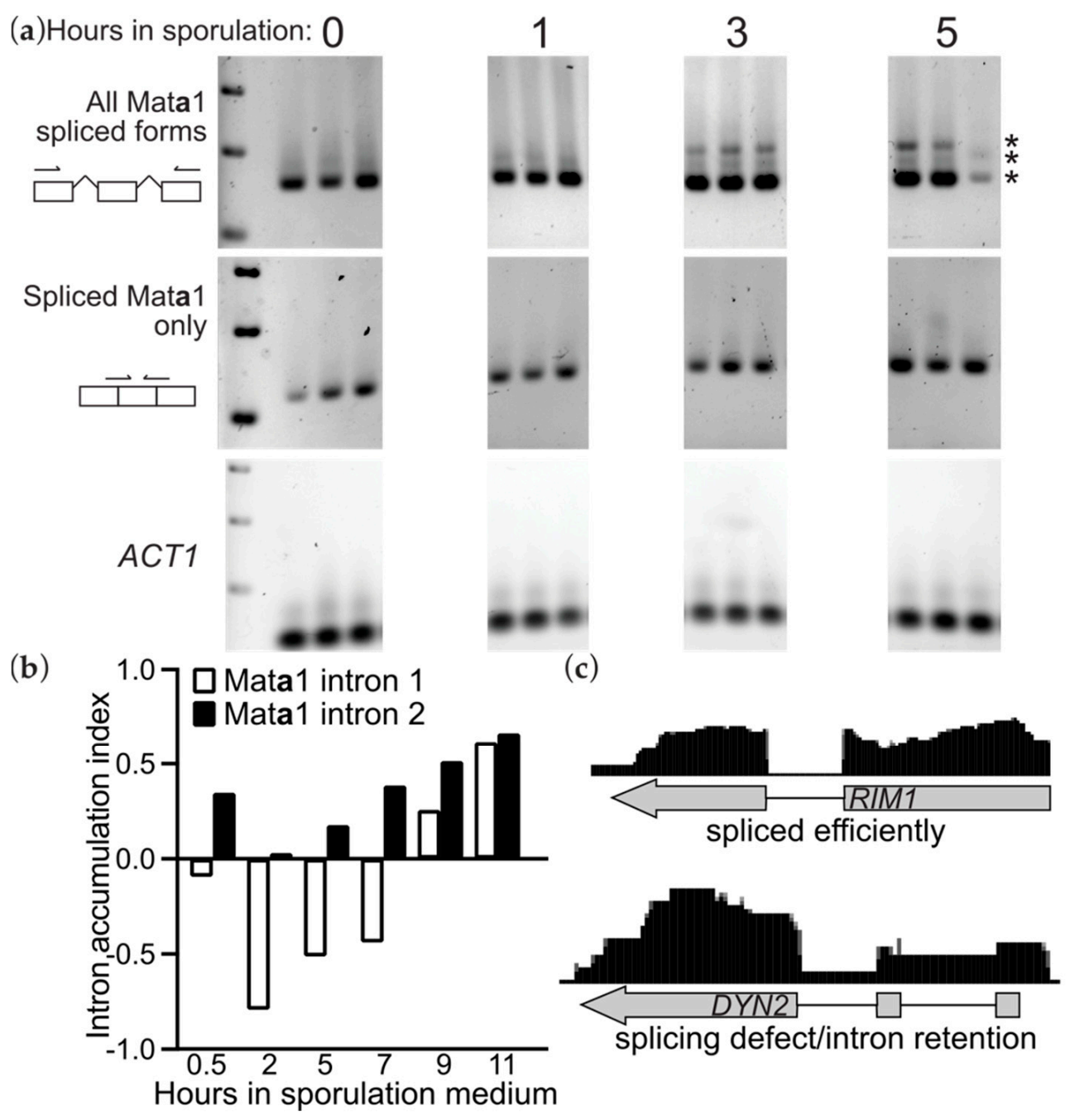

Figure 3. Intron retention in Mata1 transcripts reflects a widespread splicing defect. (a) RT-PCR was used to detect Mata1 transcripts in total RNA isolated from cells of strain FY2740 undergoing synchronous sporulation. Three biological replicates were analyzed for each sample. The left-most lane is a molecular weight marker (SM0311, Thermo-Fisher, Waltham, MA, USA) showing bands of 750, 500, and 250 basepairs. Illustrations to the left show where the Mata1 primers anneal and how they allow detection of all spliced forms or fully-spliced Mata1. Asterisks at right mark the three spliced forms. (b) Published microarray data [27] showing Mata1 intron retention in cells undergoing synchronous sporulation. (c) From our RNA-seq data, examples of a transcript that was spliced efficiently in spores-as indicated by a lack of reads mapping to the intronic sequence-and a transcript that showed, like Mata1, intron retention. See Table 1 for a list of other transcripts and their intron retention in spores. 
(a)

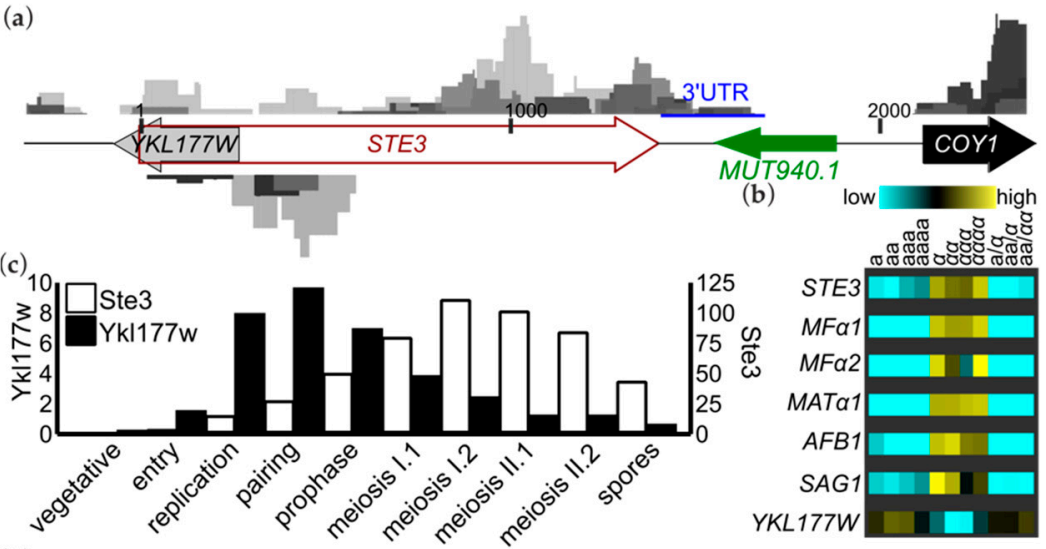

(d)

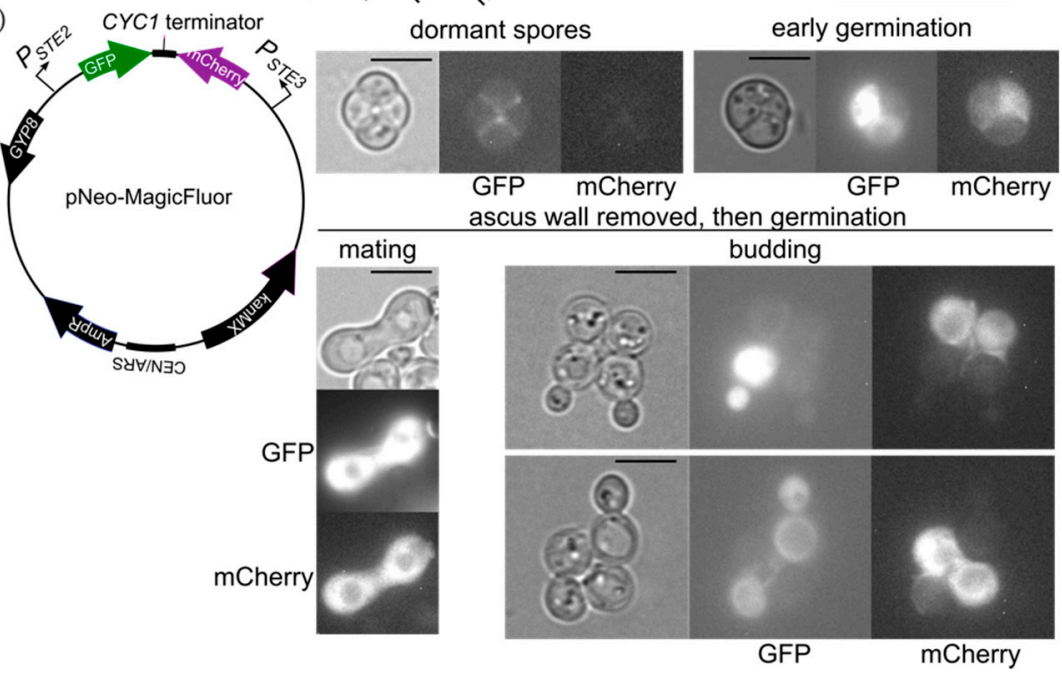

Figure 4. Ste3 and an antisense transcript, Ykl177w, co-exist in spores but the STE2 and STE3 promoters are sufficient for translational repression. (a) The structure of the STE3 gene region is illustrated with ORFs drawn as large arrows. Numbers indicate basepairs, starting at the Ste3 start codon. RNA-seq reads from our four samples (two replicates each of a and $\alpha$ spores) were mapped to each strand and are shown as grayscale peaks, color-coded by sample. Those mapping to the strand representing Ste3 transcript are shown above, and those mapping to the other strand-presumably

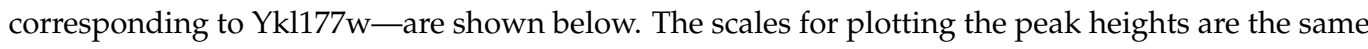
for all samples and both strands. MUT940.1 indicates a non-coding RNA found in sporulating cells in another study [31] that partially overlaps the STE3 3'UTR. (b) Heatmap showing mating-typedependent changes in gene expression based on microarray published data [32]. Source strains varied by mating type and ploidy, as indicated (e.g., "aaaa" is a tetraploid with the a allele at all four copies of MAT). (c) As in Figure 1a, RNA-seq data from [6] for Ste3 and Ykl177w. (d) The pNeo-MagicFluor plasmid carries the promoter sequences from STE2 and STE3 driving expression of GFP and mCherry, respectively. As a low-copy centromeric plasmid, it segregates randomly during sporulation and not all spores inherit it. Micrographs show transmitted light or GFP or mCherry fluorescence in mature asci in sporulation medium ("dormant spores"), following $2 \mathrm{~h}$ of exposure to rich medium ("early germination"), or following enzymatic removal of the ascus wall and $5 \mathrm{~h}$ of exposure to rich medium ("ascus wall removed, then germination"). Representative micrographs show spores undergoing mating or budding, as indicated. The pictured zygote was presumably formed from two spores from different asci. The budding spores are still attached to their meiotic sister spores by interspore bridges. Scale bars, $6 \mu \mathrm{m}$.

Examination of the published RNA-seq time-course of sporulation revealed that Ykl177w accumulates with kinetics similar to that of Ste3 (Figure 4c). The slightly earlier apparent induction of $Y K L 177 \mathrm{~W}$ compared to STE3 likely avoids extensive RNA poly- 
merase collisions that might result from simultaneous transcription. If these transcripts anneal to each other, the resulting dsRNA may inhibit Ste3 translation (see Section 4).

Our findings with STE3 inspired us to look for antisense transcripts to other "matingtype-specific" genes. We examined 27 such genes as identified previously [5] and found evidence of antisense transcripts for 10 of them, AFB1, AGA2, ASG7, BAR1, DDR2, FAR1, $H O, M F A 2, M F \alpha 2$, and SAG1 (Figure 5 and Supplementary Figure S1). With the exception of $D D R 2$, we also found antisense transcripts for each of these 10 genes in published spore RNA-seq data [6]. We arbitrarily selected 10 control genes by adding or subtracting 100 from the systematic locus identifier for each of the 10 "antisense" genes. For example, for $H O(=Y D L 227 C)$, the corresponding control was PCL2 $(=Y D L 127 W)$. For none of the control genes (FRE7, IKS1, LAP2, NUP159, PCL2, RPS26A, RRN5, SNT2, SOD1, YJL070C) did we find any evidence of antisense transcripts in spores (Supplementary Figure S1 and data not shown). These findings implicate the production of antisense transcripts during sporulation in the regulation of expression of "mating-type-specific" genes inherited by spores.

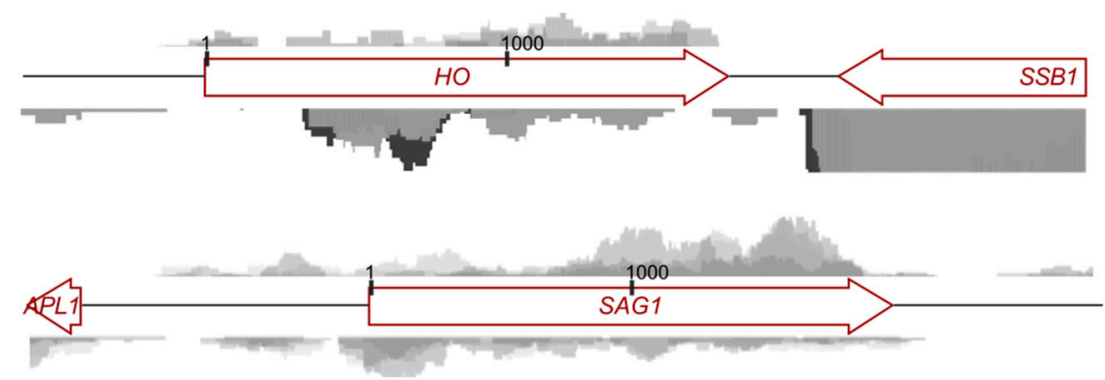

Figure 5. Antisense transcripts corresponding to $H O$ or $S A G 1$ co-exist in spores. As in Figure 4a, RNA-seq reads from sorted spores were mapped to regions of the genome surrounding the $H O$ or $S A G 1$ gene. Note that for the $H O$ gene the scale was set the same for the sense and antisense reads mapping to $H O$, but at this scale most reads from the adjacent, highly-expressed SSB1 gene exceed this scale.

\subsection{Translational Repression in Spores Mediated by the Promoters of Mating-Type-Specific Genes}

The promoters of mating-type-specific genes also appear to be sufficient to confer translational repression in spores. In vegetative haploid cells carrying a plasmid with mCherry under control of the STE3 promoter and GFP under control of the STE2 promoter, the GFP is expressed only in a cells and mCherry only in $\alpha$ vegetative cells, as expected, but mature spores express neither reporter [14]. In spores fluorescence is observed only upon germination [14], a result we recapitulated (Figure 4d). Hence, unless in the plasmid context these promoters behave differently than the endogenous ones, the STE2 and STE3 promoters are each sufficient to repress translation of the transcripts they produce. Similarly, MF $\alpha 1$, encoding $\alpha$-factor, was equally abundant in both spore populations (Figure 2a), yet in a published study a reporter in which GFP replaces the MF $\alpha 1$ ORF, GFP was detected only following germination and only in $~ 50 \%$ of spores (presumably MAT $\alpha$ ) [33]. Another way to estimate translational efficiency is to plot RNA reads against ribosome footprint reads. We plotted these published data for the mature spore samples obtained by the traditional synchronization sporulation method and noticed that $M F \alpha 1$ and three other mating-type-specific genes, BAR1, SST2, and STE2, were among the transcripts with the lowest number of ribosome-protected reads in the published data [6] (Figure S2). In summary, despite being inherited similarly by spores of each mating type, transcripts that are "mating-type-specific" in vegetative cells are particularly translationally repressed in spores. For those that have been tested directly (STE2, STE3, and MF 1 ), each displayed mating-type-specific expression only in germinating spores, and the promoters of these genes were sufficient to confer this regulation. While the underlying mechanisms in this context remain to be determined, the control of translation by yeast promoters is known to occur in other contexts [34]. 


\section{Discussion}

When it comes to meiosis/sporulation in S. cerevisiae, post-transcriptional control of gene expression appears to be the rule rather than the exception. There are numerous examples of genes that are transcribed early in the process but the protein products only appear later. Multiple mechanisms are at play and any could affect mating-type transcripts. While most examples of regulation by antisense transcripts in S. cerevisiae involve the inhibition of transcription in cis, in the case of "messenger-interacting mRNAs" (mimRNAs) produced by convergently transcribed genes, ribosomes stall at the site of overlap [35]. We detected complementary RNAs in the same cells which, if they form dsRNA, could interfere with translation. The only gene identified in both screens $[36,37]$ for mutants specifically defective in germination, TRF4/PAP2, encodes a subunit of the TRAMP (Trf4/5-Air1/2Mtr4-Polyadenylation) complex involved in degrading "aberrant" nuclear RNAs [38-40]. We speculate that upon germination the TRAMP complex targets incompletely processed nuclear transcripts, potentially including dsRNAs resulting from antisense-sense annealing, and that mating-type-specific genes are enriched among this class of transcripts in spores. TRAMP eliminates "aberrant" nuclear transcripts by polyadenylating them in a way that targets them for degradation by the exosome [39]. Interestingly, in the fission yeast Schizosaccharomyces pombe, genes that function in meiosis are transcribed in vegetative cells but the nascent transcripts are bound by the Mmi1 protein in a sequence-dependent manner, which inhibits their splicing and promotes hyperadenylation and consequent destruction by the exosome [41-43]. There is no clear Mmi1 counterpart in S. cerevisiae.

This model is consistent with the fact that spore germination is known to drive rapid and extensive decay of mRNAs that are otherwise stable for months [22], though decay could also follow a burst of translation. Microarray experiments showed that the relative abundance of mating transcripts increases starting about an hour after germination and peaking after about two hours, even in isolated spores not exposed to pheromone [23]. Thus the germination-specific expression of reporter genes under the control of STE2, STE3, or the $M F \alpha 1$ promoter may reflect translation of transcripts made following germination. Interestingly, mating transcripts also accumulate in spores exposed only to glucose, but such spores are unable to mate, pointing to persistent translational inhibition only relieved by some additional process requiring other signals (e.g., a nitrogen source) to induce the full germination program [23]. One caveat to those experiments is that relative increases in the abundance of specific transcripts during germination could represent either new transcription or persistence of those transcripts and decay of most others.

In addition to the appearance of antisense transcripts and differential splicing, during sporulation there are widespread changes in usage of alternative transcription and translation start sites (Kim Guisbert et al. 2012; Cheng et al. 2018; Eisenberg et al. 2020). Our current data do not address these mechanisms for mating-type-specific genes in spores. Modification of S. cerevisiae RNAs by $\mathrm{N}^{6}$-methyladenosine $\left(\mathrm{m}^{6} \mathrm{~A}\right)$ occurs only during sporulation, via the methyltransferase Ime4 [44,45]. >1100 transcripts, including Ste3 and Ste6, are $\mathrm{m}^{6} \mathrm{~A}$-modified but functional roles are mostly unknown [45]. Ime4 is nuclear, and $\mathrm{m}^{6} \mathrm{~A}$ modification of nascent transcripts could inhibit RNA processing and nuclear export, or could alter mRNA half-life. Mata1 does not appear to be $\mathrm{m}^{6} \mathrm{~A}$ modified [15]. Thus, we think it is unlikely that $\mathrm{m}^{6} \mathrm{~A}$ directly affects Mata1 splicing or stability.

RNA-binding proteins bind and control the translational timing of various mRNAs that are transcribed early during sporulation but are not translated until later [46-48]. Whether mating-type transcripts are bound in messenger ribonucleoprotein (mRNP) complexes during sporulation and in mature spores is unknown. However, a recent study showed that in vegetative cells many mating-type RNAs, including Ste3 and the pheromone-encoding transcripts MF $\alpha 1$ and $M F \alpha 2$, are bound together in mRNPs that the authors called "transperons" [49]. Transcripts in transperons co-localize both before and after nuclear export and were presumed to have similar translational fates [49]. The STE2 and AGA2 loci come in close proximity in vegetative cells, suggesting that transperon assembly is co-transcriptional [49]. A cis-acting 47-nucleotide sequence found in STE2 and 
four other mating genes is important for transperon assembly [49]. The fact that these sequences, like the antisense Ste 3 transcripts we found in spores, are in coding regions suggests that neither transperon- or antisense-mediated repression is sufficient to explain the promoter-driven translational repression we observed for STE2 and STE3 using the reporter plasmid (Figure $4 \mathrm{~d}$ ).

We were surprised to find that the transcriptomes of spores of both mating types were so similar. At first glance, the presence of normally a-specific transcripts in an $\alpha$ spore would seem to risk sexual confusion upon germination. Indeed, ectopically expressed Ste3 in a cells does bind the a-factor produced by the same cells, but this autocrine signal does not trigger the downstream responses that normally accompany pheromone sensing. Instead, the activity of the $G$ protein $\beta$ subunit, Ste4, is inhibited in a process termed receptor inhibition, blocking downstream signaling and thus inhibiting the ability of $\alpha$-factor-bound Ste2 to initiate the mating response [11,50-52]. When spores germinate they frequently avail themselves of a nearby mating partner and mate immediately following a short period of outgrowth of new cell wall $[33,53]$. In this context, receptor inhibition resulting from the presence of both pheromones and both receptors would disfavor mating and promote budding. In fact, in some S. cerevisiae strains, this is precisely what is observed: spores forego sex and bud instead [33]. For strains in which spores were more likely to mate, $\alpha$ factor production was generally higher and, for some, the MF $\alpha 1$ gene encoded more copies of the pheromone-peptide-encoding sequences [33]. Some degree of receptor inhibition due to translation of "residual" inappropriate transcripts like Ste3 could contribute to this state of limiting pheromone. Interestingly, the transcript with the lowest composite translational efficiency in spores is Dig2 [6]. Dig2 protein binds Ste12, a key activator of mating genes in both mating types, and both inhibits it and protects it from degradation. The resulting pool of inactive Ste12 becomes active when pheromone triggers Dig2 phosphorylation and release from Ste12 [54-59]. The extent to which translational repression of inherited Dig2 transcripts is reversed upon spore germination could also influence the bud-vs-mate decision. Overall, then, the simplest model for the fate of inherited transcripts representing a mix of both mating types is that they are mostly translationally repressed and have minor, if any, phenotypic consequences.

Though we cannot rule out an unknown function in spores, Mata1 protein has no known function in vegetative a cells. If Mata1 protein is present in cells that also express MAT $\alpha 2$, the Mata1-Mat $\alpha 2$ heterodimer, which is rather long-lived [60], might repress transcription of important mating genes. Hence from the perspective of spore mating the most important fate of Mata1 is its absence in MAT $\alpha$ cells. The accumulation of unspliced Mata1 late in sporulation offers two possible mechanisms of biased inheritance. Slow Mata1 splicing means that fully spliced Mata1 was probably transcribed early. In vegetative cells unspliced Mata1 transcript escapes cytoplasmic nonsense-mediated decay and is instead destroyed by nuclear RNA decay pathways, which has been proposed to reflect nuclear retention of the unspliced transcript [29]. The decrease in fully spliced Mata1 late thus may indicate RNA decay from which unspliced or newly-made Mata1 is protected. Decay of spliced Mata1 past the point of meiotic anaphase II and spore isolation would enforce spore autonomy of Mata1 inheritance. A second, non-exclusive mechanism relates to the fact that in RNA processing mutants some nascent transcripts remain associated with the locus of origin [61]. Thus, Mata1 transcripts could be physically linked to the MATa1 gene and segregate with it during meiotic chromosome segregation.

Indeed, in mammalian cells, there are multiple examples of programmed intron retention as an apparent cellular strategy to sequester transcripts in the nucleus and even on chromatin, preventing the synthesis of proteins in inappropriate developmental contexts $[62,63]$. In meiotic spermatocytes, intron retention-resulting from high transcription rates outpacing splicing capacity-leads to long-lived transcripts encoding proteins with key functions in gametes [62]. While parallels with our observations are striking, a crucial distinction is that, rather than males producing sperm and females producing eggs, in $S$. cerevisiae a single cell type $(\mathbf{a} / \alpha)$ produces gametes of two distinct mating types, necessi- 
tating an additional layer of regulation. Dissecting in further detail the genetic circuitry underlying this example of cellular differentiation will be fertile ground for future research.

Supplementary Materials: The following are available online at https:/ / www.mdpi.com/article/ 10.3390/biom11081223/s1. Figure S1: Spores harbor antisense transcripts to many "mating-typespecific" genes, Figure S2: Limited translation in spores of mating-type-specific transcripts, Figure S3: $\mathrm{m}^{6} \mathrm{~A}$ methylation promotes Mata1 induction during sporulation. Table S1: Differentially abundant transcripts in spores sorted by mating type, according to edgeR analysis.

Author Contributions: Conceptualization, R.Y. and M.M.; methodology, R.Y., M.M., G.G.B. and R.F.; software, R.F. and B.C.; investigation, R.Y., E.S. and G.G.B.; data curation, B.C. and R.F.; writing—original draft preparation, M.M.; writing—review and editing, M.M., R.Y., G.G.B., E.S., R.F. and B.C.; visualization, M.M.; supervision, M.M.; project administration, M.M.; funding acquisition, M.M. and G.G.B. All authors have read and agreed to the published version of the manuscript.

Funding: This research was funded by an RNA-seq Pilot Grant from the RNA Biosciences Initiative of the University of Colorado School of Medicine, by the National Science Foundation, grant number 1928900, by the National Cancer Institute of the National Institutes of Health, grant number P30CA046934, and by the National Institute of General Medical Sciences of the National Institutes of Health, grant numbers T32GM008730, F32GM108201, and R01GM035010. The APC was funded by the National Science Foundation, grant number 1928900.

Institutional Review Board Statement: Not applicable.

Informed Consent Statement: Not applicable.

Data Availability Statement: Most data are contained within the article or Supplementary Material. The RNA-seq data obtained in this study are openly available in the GEO database (accession number GSE180221). RNA-seq and Ribo-seq publicly available dataset GEO GSE34082 was also analyzed in this study. Microarray data from Supplementary Data of two published studies were taken either from the study directly [27] or accessed and plotted via the SPELL search engine (version 2.0.3r71) [32,64] running on the Saccharomyces Genome Database (http:/ / yeastgenome.org, accessed on 16 August 2020).

Acknowledgments: The RT-PCR experiments were performed in the laboratory of Gerry Fink and we thank him for his support. We are indebted to Garrett Hedlund, Manager of the Flow Core, for assistance with FACS, and to the Genomics Shared Resource for assistance with RNA-seq. We thank Folkert Van Werven for the FW2444 strain and detailed protocol, Gloria Brar for helpful discussions, and Trisha Wittkopp for the pBC58 plasmid.

Conflicts of Interest: The authors declare no conflict of interest. The funders had no role in the design of the study; in the collection, analyses, or interpretation of data; in the writing of the manuscript, or in the decision to publish the results.

\section{References}

1. Sprague, G.F.; Blair, L.C.; Thorner, J. Cell interactions and regulation of cell type in the yeast Saccharomyces cerevisiae. Annu. Rev. Microbiol. 1983, 37, 623-660. [CrossRef] [PubMed]

2. Nasmyth, K.; Shore, D. Transcriptional regulation in the yeast life cycle. Science 1987, 237, 1162-1170. [CrossRef] [PubMed]

3. Herskowitz, I. A regulatory hierarchy for cell specialization in yeast. Nature 1989, 342, 749-757. [CrossRef] [PubMed]

4. Haber, J.E. Mating-type genes and MAT switching in Saccharomyces cerevisiae. Genetics 2012, 191, 33-64. [CrossRef]

5. Galgoczy, D.J.; Cassidy-Stone, A.; Llinás, M.; O’Rourke, S.M.; Herskowitz, I.; DeRisi, J.L.; Johnson, A.D. Genomic dissection of the cell-type-specification circuit in Saccharomyces cerevisiae. Proc. Natl. Acad. Sci. USA 2004, 101, 18069-18074. [CrossRef]

6. Brar, G.A.; Yassour, M.; Friedman, N.; Regev, A.; Ingolia, N.T.; Weissman, J.S. High-resolution view of the yeast meiotic program revealed by ribosome profiling. Science 2012, 335, 552-557. [CrossRef]

7. Chin, B.L.; Frizzell, M.A.; Timberlake, W.E.; Fink, G.R. FASTER MT: Isolation of Pure Populations of a and $\alpha$ Ascospores from Saccharomycescerevisiae. G3 Genes Genomes Genet. 2012, 2, 449-452. [CrossRef]

8. Herskowitz, I. Life cycle of the budding yeast Saccharomyces cerevisiae. Microbiol. Rev. 1988, 52, 536-553. [CrossRef]

9. Hicks, J.B.; Herskowitz, I. Interconversion of Yeast Mating Types I. Direct Observations of the Action of the Homothallism (HO) Gene. Genetics 1976, 83, 245-258. [CrossRef]

10. Laney, J.D.; Hochstrasser, M. Ubiquitin-dependent degradation of the yeast Mat(alpha)2 repressor enables a switch in developmental state. Genes Dev. 2003, 17, 2259-2270. [CrossRef] 
11. Hirsch, J.P.; Cross, F.R. The pheromone receptors inhibit the pheromone response pathway in Saccharomyces cerevisiae by a process that is independent of their associated $G$ alpha protein. Genetics 1993, 135, 943-953. [CrossRef] [PubMed]

12. Chia, M.; van Werven, F.J. Temporal Expression of a Master Regulator Drives Synchronous Sporulation in Budding Yeast. G3 Genes Genomes Genet. 2016, 6, 3553-3560. [CrossRef] [PubMed]

13. Deutschbauer, A.M.; Davis, R.W. Quantitative trait loci mapped to single-nucleotide resolution in yeast. Nat. Genet. 2005, 37, 1333-1340. [CrossRef] [PubMed]

14. Treusch, S.; Albert, F.W.; Bloom, J.S.; Kotenko, I.E.; Kruglyak, L. Genetic mapping of MAPK-mediated complex traits Across S. cerevisiae. PLoS Genet. 2015, 11, e1004913. [CrossRef]

15. Bushkin, G.G.; Pincus, D.; Morgan, J.T.; Richardson, K.; Lewis, C.; Chan, S.H.; Bartel, D.P.; Fink, G.R. m6A modification of a 3' UTR site reduces RME1 mRNA levels to promote meiosis. Nat. Commun. 2019, 10, 3414. [CrossRef]

16. Robinson, M.D.; McCarthy, D.J.; Smyth, G.K. edgeR: A Bioconductor package for differential expression analysis of digital gene expression data. Bioinformatics 2010, 26, 139-140. [CrossRef]

17. Kent, W.J.; Sugnet, C.W.; Furey, T.S.; Roskin, K.M.; Pringle, T.H.; Zahler, A.M.; Haussler, D. The human genome browser at UCSC. Genome Res. 2002, 12, 996-1006. [CrossRef]

18. Robinson, J.T.; Thorvaldsdóttir, H.; Winckler, W.; Guttman, M.; Lander, E.S.; Getz, G.; Mesirov, J.P. Integrative genomics viewer. Nat. Biotechnol. 2011, 29, 24-26. [CrossRef]

19. Schindelin, J.; Arganda-Carreras, I.; Frise, E.; Kaynig, V.; Longair, M.; Pietzsch, T.; Preibisch, S.; Rueden, C.; Saalfeld, S.; Schmid, B.; et al. Fiji: An open-source platform for biological-image analysis. Nat. Methods 2012, 9, 676-682. [CrossRef]

20. Thacker, D.; Lam, I.; Knop, M.; Keeney, S. Exploiting spore-autonomous fluorescent protein expression to quantify meiotic chromosome behaviors in Saccharomyces cerevisiae. Genetics 2011, 189, 423-439. [CrossRef]

21. Rogers, D.W.; McConnell, E.; Ono, J.; Greig, D. Spore-autonomous fluorescent protein expression identifies meiotic chromosome mis-segregation as the principal cause of hybrid sterility in yeast. PLoS Biol. 2018, 16, e2005066. [CrossRef]

22. Brengues, M.; Pintard, L.; Lapeyre, B. mRNA decay is rapidly induced after spore germination of Saccharomyces cerevisiae. J. Biol. Chem. 2002, 277, 40505-40512. [CrossRef]

23. Joseph-Strauss, D.; Zenvirth, D.; Simchen, G.; Barkai, N. Spore germination in Saccharomyces cerevisiae: Global gene expression patterns and cell cycle landmarks. Genome Biol. 2007, 8, R241. [CrossRef]

24. Wach, A.; Brachat, A.; Pöhlmann, R.; Philippsen, P. New heterologous modules for classical or PCR-based gene disruptions in Saccharomyces cerevisiae. Yeast 1994, 10, 1793-1808. [CrossRef]

25. Bitter, G.A.; Egan, K.M. Expression of heterologous genes in Saccharomyces cerevisiae from vectors utilizing the glyceraldehyde3-phosphate dehydrogenase gene promoter. Gene 1984, 32, 263-274. [CrossRef]

26. Miller, A.M. The yeast MATa1 gene contains two introns. EMBO J. 1984, 3, 1061-1065. [CrossRef]

27. Munding, E.M.; Shiue, L.; Katzman, S.; Donohue, J.P.; Ares, M. Competition between pre-mRNAs for the splicing machinery drives global regulation of splicing. Mol. Cell 2013, 51, 338-348. [CrossRef]

28. Parenteau, J.; Durand, M.; Véronneau, S.; Lacombe, A.-A.; Morin, G.; Guérin, V.; Cecez, B.; Gervais-Bird, J.; Koh, C.-S.; Brunelle, D.; et al . Deletion of many yeast introns reveals a minority of genes that require splicing for function. Mol. Biol. Cell 2008, 19, 1932-1941. [CrossRef]

29. Egecioglu, D.E.; Kawashima, T.R.; Chanfreau, G.F. Quality control of MATa1 splicing and exon skipping by nuclear RNA degradation. Nucleic Acids Res. 2012, 40, 1787-1796. [CrossRef]

30. Hongay, C.F.; Grisafi, P.L.; Galitski, T.; Fink, G.R. Antisense transcription controls cell fate in Saccharomyces cerevisiae. Cell 2006, 127, 735-745. [CrossRef]

31. Lardenois, A.; Liu, Y.; Walther, T.; Chalmel, F.; Evrard, B.; Granovskaia, M.; Chu, A.; Davis, R.W.; Steinmetz, L.M.; Primig, M Execution of the meiotic noncoding RNA expression program and the onset of gametogenesis in yeast require the conserved exosome subunit Rrp6. Proc. Natl. Acad. Sci. USA 2011, 108, 1058-1063. [CrossRef]

32. Galitski, T.; Saldanha, A.J.; Styles, C.A.; Lander, E.S.; Fink, G.R. Ploidy regulation of gene expression. Science 1999, $285,251-254$. [CrossRef]

33. McClure, A.W.; Jacobs, K.C.; Zyla, T.R.; Lew, D.J. Mating in wild yeast: Delayed interest in sex after spore germination. Mol. Biol. Cell 2018, 29, 3119-3127. [CrossRef] [PubMed]

34. Zid, B.M.; O'Shea, E.K. Promoter sequences direct cytoplasmic localization and translation of mRNAs during starvation in yeast. Nature 2014, 514, 117-121. [CrossRef]

35. Sinturel, F.; Navickas, A.; Wery, M.; Descrimes, M.; Morillon, A.; Torchet, C.; Benard, L. Cytoplasmic Control of Sense-Antisense mRNA Pairs. Cell Rep. 2015, 12, 1853-1864. [CrossRef] [PubMed]

36. Deutschbauer, A.M.; Williams, R.M.; Chu, A.M.; Davis, R.W. Parallel phenotypic analysis of sporulation and postgermination growth in Saccharomyces cerevisiae. Proc. Natl. Acad. Sci. USA 2002, 99, 15530-15535. [CrossRef] [PubMed]

37. Kloimwieder, A.; Winston, F. A Screen for Germination Mutants in Saccharomyces cerevisiae. G3 Genes Genomes Genet. 2011, 1, 143-149. [CrossRef]

38. Vanácová, S.; Wolf, J.; Martin, G.; Blank, D.; Dettwiler, S.; Friedlein, A.; Langen, H.; Keith, G.; Keller, W. A new yeast poly(A) polymerase complex involved in RNA quality control. PLoS Biol. 2005, 3, e189. [CrossRef]

39. LaCava, J.; Houseley, J.; Saveanu, C.; Petfalski, E.; Thompson, E.; Jacquier, A.; Tollervey, D. RNA degradation by the exosome is promoted by a nuclear polyadenylation complex. Cell 2005, 121, 713-724. [CrossRef] [PubMed] 
40. Wyers, F.; Rougemaille, M.; Badis, G.; Rousselle, J.-C.; Dufour, M.-E.; Boulay, J.; Régnault, B.; Devaux, F.; Namane, A.; Séraphin, B.; et al. Cryptic pol II transcripts are degraded by a nuclear quality control pathway involving a new poly(A) polymerase. Cell 2005, 121, 725-737. [CrossRef] [PubMed]

41. Chen, H.-M.; Futcher, B.; Leatherwood, J. The fission yeast RNA binding protein Mmi1 regulates meiotic genes by controlling intron specific splicing and polyadenylation coupled RNA turnover. PLoS ONE 2011, 6, e26804. [CrossRef] [PubMed]

42. Yamashita, A.; Shichino, Y.; Tanaka, H.; Hiriart, E.; Touat-Todeschini, L.; Vavasseur, A.; Ding, D.-Q.; Hiraoka, Y.; Verdel, A.; Yamamoto, M. Hexanucleotide motifs mediate recruitment of the RNA elimination machinery to silent meiotic genes. Open Biol. 2012, 2, 120014. [CrossRef] [PubMed]

43. Kilchert, C.; Wittmann, S.; Passoni, M.; Shah, S.; Granneman, S.; Vasiljeva, L. Regulation of mRNA Levels by Decay-Promoting Introns that Recruit the Exosome Specificity Factor Mmi1. Cell Rep. 2015, 13, 2504-2515. [CrossRef] [PubMed]

44. Clancy, M.J.; Shambaugh, M.E.; Timpte, C.S.; Bokar, J.A. Induction of sporulation in Saccharomyces cerevisiae leads to the formation of N6-methyladenosine in mRNA: A potential mechanism for the activity of the IME4 gene. Nucleic Acids Res. 2002, 30, 4509-4518. [CrossRef] [PubMed]

45. Schwartz, S.; Agarwala, S.D.; Mumbach, M.R.; Jovanovic, M.; Mertins, P.; Shishkin, A.; Tabach, Y.; Mikkelsen, T.S.; Satija, R.; Ruvkun, G.; et al. High-resolution mapping reveals a conserved, widespread, dynamic mRNA methylation program in yeast meiosis. Cell 2013, 155, 1409-1421. [CrossRef] [PubMed]

46. Berchowitz, L.E.; Gajadhar, A.S.; van Werven, F.J.; De Rosa, A.A.; Samoylova, M.L.; Brar, G.A.; Xu, Y.; Xiao, C.; Futcher, B.; Weissman, J.S.; et al. A developmentally regulated translational control pathway establishes the meiotic chromosome segregation pattern. Genes Dev. 2013, 27, 2147-2163. [CrossRef]

47. Jin, L.; Zhang, K.; Xu, Y.; Sternglanz, R.; Neiman, A.M. Sequestration of mRNAs Modulates the Timing of Translation during Meiosis in Budding Yeast. Mol. Cell. Biol. 2015, 35, 3448-3458. [CrossRef]

48. Jin, L.; Zhang, K.; Sternglanz, R.; Neiman, A.M. Predicted RNA Binding Proteins Pes4 and Mip6 Regulate mRNA Levels, Translation, and Localization during Sporulation in Budding Yeast. Mol. Cell. Biol. 2017, 37. [CrossRef]

49. Nair, R.R.; Zabezhinsky, D.; Gelin-Licht, R.; Haas, B.J.; Dyhr, M.C.; Sperber, H.S.; Nusbaum, C.; Gerst, J.E. Multiplexed mRNA assembly into ribonucleoprotein particles plays an operon-like role in the control of yeast cell physiology. Elife 2021, 10, e66050. [CrossRef]

50. Roth, A.F.; Nelson, B.; Boone, C.; Davis, N.G. Asg7p-Ste3p inhibition of pheromone signaling: Regulation of the zygotic transition to vegetative growth. Mol. Cell. Biol. 2000, 20, 8815-8825. [CrossRef]

51. Robertson, C.G.; Clark-Cotton, M.R.; Lew, D.J. Mechanisms that ensure monogamous mating in Saccharomyces cerevisiae. Mol. Biol. Cell 2021, 32, 638-644. [CrossRef] [PubMed]

52. Kim, J.; Bortz, E.; Zhong, H.; Leeuw, T.; Leberer, E.; Vershon, A.K.; Hirsch, J.P. Localization and signaling of G(beta) subunit Ste4p are controlled by a-factor receptor and the a-specific protein Asg7p. Mol. Cell. Biol. 2000, 20, 8826-8835. [CrossRef] [PubMed]

53. Heasley, L.R.; Singer, E.; Cooperman, B.J.; McMurray, M.A. Saccharomyces spores are born prepolarized to outgrow away from spore-spore connections and penetrate the ascus wall. Yeast Chichester Engl. 2021, 38, 90-101. [CrossRef] [PubMed]

54. Cook, J.G.; Bardwell, L.; Kron, S.J.; Thorner, J. Two novel targets of the MAP kinase Kss1 are negative regulators of invasive growth in the yeast Saccharomyces cerevisiae. Genes Dev. 1996, 10, 2831-2848. [CrossRef] [PubMed]

55. Tedford, K.; Kim, S.; Sa, D.; Stevens, K.; Tyers, M. Regulation of the mating pheromone and invasive growth responses in yeast by two MAP kinase substrates. Curr. Biol. 1997, 7, 228-238. [CrossRef]

56. Pi, H.; Chien, C.T.; Fields, S. Transcriptional activation upon pheromone stimulation mediated by a small domain of Saccharomyces cerevisiae Ste12p. Mol. Cell. Biol. 1997, 17, 6410-6418. [CrossRef] [PubMed]

57. Bardwell, L.; Cook, J.G.; Zhu-Shimoni, J.X.; Voora, D.; Thorner, J. Differential regulation of transcription: Repression by unactivated mitogen-activated protein kinase Kss1 requires the Dig1 and Dig2 proteins. Proc. Natl. Acad. Sci. USA 1998, 95, 15400-15405. [CrossRef]

58. Olson, K.A.; Nelson, C.; Tai, G.; Hung, W.; Yong, C.; Astell, C.; Sadowski, I. Two regulators of Ste12p inhibit pheromone-responsive transcription by separate mechanisms. Mol. Cell. Biol. 2000, 20, 4199-4209. [CrossRef] [PubMed]

59. Houser, J.R.; Ford, E.; Nagiec, M.J.; Errede, B.; Elston, T.C. Positive roles for negative regulators in the mating response of yeast. Mol. Syst. Biol. 2012, 8, 586. [CrossRef]

60. Johnson, P.R.; Swanson, R.; Rakhilina, L.; Hochstrasser, M. Degradation signal masking by heterodimerization of MATalpha2 and MATa1 blocks their mutual destruction by the ubiquitin-proteasome pathway. Cell 1998, 94, 217-227. [CrossRef]

61. Paul, B.; Montpetit, B. Altered RNA processing and export lead to retention of mRNAs near transcription sites and nuclear pore complexes or within the nucleolus. Mol. Biol. Cell 2016, 27, 2742-2756. [CrossRef] [PubMed]

62. Naro, C.; Jolly, A.; Di Persio, S.; Bielli, P.; Setterblad, N.; Alberdi, A.J.; Vicini, E.; Geremia, R.; De la Grange, P.; Sette, C. An Orchestrated Intron Retention Program in Meiosis Controls Timely Usage of Transcripts during Germ Cell Differentiation. Dev. Cell 2017, 41, 82-93. [CrossRef] [PubMed]

63. Yeom, K.-H.; Pan, Z.; Lin, C.-H.; Lim, H.Y.; Xiao, W.; Xing, Y.; Black, D.L. Tracking pre-mRNA maturation across subcellular compartments identifies developmental gene regulation through intron retention and nuclear anchoring. Genome Res. 2021, 31, 1106-1119. [CrossRef] [PubMed]

64. Hibbs, M.A.; Hess, D.C.; Myers, C.L.; Huttenhower, C.; Li, K.; Troyanskaya, O.G. Exploring the functional landscape of gene expression: Directed search of large microarray compendia. Bioinformatics 2007, 23, 2692-2699. [CrossRef] [PubMed] 